\title{
RANCANGAN PERCOBAAN PENGAMATAN BERULANG UNTUK ANALISIS PENGARUH INTERAKSI CAHAYA DAN MEDIA TANAM TERHADAP PERTUMBUHAN DAN PERKEMBANGAN PERKECAMBAHAN KACANG HIJAU
}

\author{
Fadjryani ${ }^{1}$ \\ 1Staf Pengajar Program Studi Statistika Jurusan Matematika FMIPA Universitas Tadulako \\ Jalan Soekarno-Hatta Km. 09 Tondo, Palu 94118, Indonesia. \\ Fadjryani_mipauntad@yahoo.com
}

\begin{abstract}
Mung bean is a kind of cash crops containing higher mineral and protein. Seed is a part of the mung bean plants that have economic value. Mung bean seed planted in certain medium will thrive and grow into sprouts. Germination is an initial process of growth and development of the seeds into a new plant. To produce stem sprouts that have good quality of growth then it is necessary to conduct a research on the mung bean sprouts. The purpose of this study was to determine the effect of combined treatment interaction with time on growth and development of the mung bean germination. This study was carried out for over 7 (seven) days at biology laboratory FMIPA, Tadulako University. This study is an experiment repeated observations using two-factor factorial design and a completely randomized design as a design environment. Such a plan is called a factorial design in RAL (A Completely Randomized Design). The first factor is the intensity of light (IC), which consists of three levels, namely: mung beans were placed in a dark place or a place that is not exposed to sunlight at all (C1), a shady place or a place that gets indirect sunlight (C2), bright spots or places that receive direct sunlight (C3). The second factor is the growing medium consisting of 2 types of wetlands (MT1) and cotton (MT2). Responses observed in this study is the growth and development of mung bean germination. observation of responses carried for seven days. Number of combination treatment was 6 units. For each treatment combination places 5 mung beans seeds. Mung beans used in this experiment were considered to have similar quality. The experiment was repeated for 3 times so there were 18 units of the experiments. Each experimental unit was watering with the same volume of water. From the Anova (Analysis of Variance) it is concluded that the light intensity factor $(\mathrm{C} 1)$, the planting medium (MT), time $(C)$, interactions $I C^{*} C, C^{*} M T$ interaction and interaction $I C^{*} \mathrm{MT}^{\star} \mathrm{C}$ has a significant effect on the response observed which is indicated by the $\mathrm{p}$ value of less than $5 \%$ a (significance level) (0.00001) while the interaction between IC*MT did not significantly affect the response observed $(p=0.6098>5)$. Based on the results of Duncan's multiple comparisons, it was obtained a fact that IC1 was significantly different from IC2 and IC3. Response of stem growth for IC2 was longer than IC1 and IC3.
\end{abstract}


MT1 was also significantly different from MT2. MT1 produced longer plants compared with MT2, while the influence of time $\mathrm{C} 1, \mathrm{C} 2, \mathrm{C} 3, \mathrm{C} 4, \mathrm{C} 5, \mathrm{C} 6$, and $\mathrm{C} 7$ were significantly different to the response observed. This was proved by the increasing length of the stems of the plants along with increasing time.

\section{Keywords $\quad$ : Factorial in RAL, Mung Bean, Sprout}

\section{ABSTRAK}

Kacang hijau adalah sejenis tanaman palawija yang mengandung mineral dan protein yang tinggi. Bagian yang bernilai ekonomis dari kacang hijau adalah bijinya. Biji kacang hijau yang ditanam pada media tertentu akan tumbuh dan berkembang menjadi kecambah. Kecambah merupakan proses awal pertumbuhan dan perkembangan biji menjadi tumbuhan baru. Dalam rangka menghasilkan pertumbuhan batang kecambah yang berkualitas, dilakukan penelitian terhadap kecambah kacang hijau. Tujuan dari penelitian ini adalah untuk mengetahui pengaruh interaksi kombinasi perlakuan dengan waktu terhadap pertumbuhan dan perkembangan perkecambahan kacang hijau. Penelitian ini dilakukan selama 7 (tujuh) hari di Laboratorium Biologi FMIPA Universitas Tadulako. Penelitian ini merupakan percobaan pengamatan berulang dengan rancangan dasar faktorial dua faktor dan menggunakan rancangan lingkungannya adalah rancangan acak lengkap. Rancangan semacam ini disebut rancangan Faktorial dalam waktu RAL. Faktor pertama adalah intensitas cahaya (IC) yang terdiri dari 3 (tiga) taraf yaitu biji kacang hijau yang diletakkan pada tempat gelap atau tempat yang tidak terkena cahaya matahari sama sekali (C1), redup atau tempat yang mendapat cahaya matahari secara tidak langsung (C2) dan terang atau tempat yang mendapat cahaya secara langsung (C3). Faktor kedua adalah Media tanam, terdiri dari 2 taraf yaitu tanah lembab (MT1) dan kapas (MT2). Respon yang diamati adalah pertumbuhan dan perkembangan perkecambahan kacang hijau. Pengamatan terhadap respon dilakukan selama 7 (tujuh) hari. Jumlah kombinasi perlakuan sebanyak 6 buah. Pada setiap kombinasi perlakuan diletakkan 5 (lima) biji kacang hijau. Biji kacang hijau yang digunakan dianggap memiliki kualitas yang seragam. Percobaan tersebut diulang sebanyak 3 kali sehingga unit percobaan sebanyak 18 unit. Tiap unit percobaan diberi perlakuan berupa penyiraman air dengan volume yang sama. Dari tabel sidik ragam diperoleh kesimpulan bahwa faktor intensitas cahaya (IC), media tanam (MT), waktu (C), interaksi IC ${ }^{*} \mathrm{C}$, interaksi $M T^{*} \mathrm{C}$ dan interaksi $I C^{*} M T^{\star} \mathrm{C}$ berpengaruh nyata terhadap respon yang diamati yang ditunjukkan dengan perolehan nilai $p$ yang kurang dari taraf nyata $5 \%$ $(0,0001)$ sedangkan untuk interaksi antara IC* MT tidak berpengaruh nyata terhadap respon yang diamati (nilai $p$ $=0,6098>0,05$ ). Berdasarkan hasil dari perbandingan berganda Duncan diperoleh fakta bahwa IC2 berbeda nyata dengan IC1 dan IC3. Respon pertumbuhan batang tanaman untuk faktor IC2 lebih panjang dibandingkan IC1 dan IC3. Demikian pula halnya dengan MT1 berbeda nyata dengan MT2. MT1 menghasilkan pertumbuhan respon lebih panjang jika dibandingkan dengan MT2. Sedangkan pengaruh waktu C1, C2, C3, C4, C5, C6 dan C7 sangat berbeda nyata terhadap respon yang diamati. Hal ini terbukti dengan semakin panjangnya batang tanaman seiring dengan bertambahnya waktu.

\section{Kata Kunci $\quad$ : Faktorial dalam waktu RAL, Kacang Hijau, Kecambah}




\section{PENDAHULUAN}

Di Indonesia, kacang hijau menempati urutan ketiga terpenting sebagai tanaman pangan legum, setelah kedelai dan kacang tanah. Kacang hijau adalah sejenis tanaman budidaya dan palawija yang dikenal luas di daerah tropika. Tumbuhan yang termasuk suku polong-polongan ini memiliki banyak manfaat dalam kehidupan sehari-hari sebagai sumber mineral dan protein yang tinggi. Bagian yang paling bernilai ekonomi dari kacang hijau adalah bijinya.

Biji kacang hijau banyak digunakan oleh manusia sebagai bahan pangan. Salah satu contoh makanan yang berasal dari biji kacang hijau yang sering dikonsumsi di kawasan Asia adalah tauge. Tauge adalah bahan sayur-sayuran hasil dari pertumbuhan dan perkembangan biji menjadi tumbuhan baru yang disebut kecambah.

Perkecambahan merupakan proses awal yang penting untuk kehidupan tanaman. Proses tersebut dimulai dengan penyerapan air oleh biji. Biji menyerap air dari lingkungan di sekelilingnya, baik melalui tanah maupun dari udara. Penyerapan air melalui udara bisa dalam bentuk uap air ataupun embun. Akibat penyerapan air, ukuran biji membesar dan menjadi lunak.

Dalam rangka menghasilkan kecambah yang berkualitas dibutuhkan biji-bijian yang sehat, tidak busuk, dan bersih dari pestisida serta lingkungan yang optimal. Biji yang sehat dipengaruhi oleh faktor genetik yang berasal dari dalam tubuh tumbuhan. Sedangkan lingkungan yang baik merupakan bagian penting dari faktor ekstern tumbuhan. Ada banyak faktor ekstern yang berasal dari lingkungan di sekitar perkecambahan diantaranya adalah kondisi cahaya dan jenis media tanam yang digunakan. Faktor-faktor tersebut harus tersedia secara optimum pada saat biji mengalami proses perkecambahan.

Cahaya merupakan faktor mutlak yang diperlukan tumbuhan untuk melakukan proses fotosintesis. Kebutuhan akan cahaya berbeda-beda untuk setiap tumbuhan. Ada jenis-jenis tumbuhan yang memerlukan cahaya penuh dan ada pula yang memerlukan cahaya yang remangremang untuk pertumbuhannya. Disamping cahaya, media tanam juga penting dalam perkecambahan. Media yang digunakan untuk perkecambahan harus mempunyai porositas yang tinggi dan mampu menjaga aerasi. Ada beberapa media tanam atau bahan yang dapat digunakan sebagai media perkecambahan biji antara lain tanah dan kapas.

Tanah berfungsi sebagai media utama tempat ditanamnya tumbuhan dalam mendukung pertumbuhan dan perkembangannya. Selain tanah, kapas juga bisa digunakan sebagai alternatif media tanam karena dapat menahan biji kacang hijau agar tidak sepenuhnya terendam air ketika di 
beri air. Kapas juga kuat untuk menggantikan tanah sebagai tempat menancapnya bakal akar pada pertumbuhan biji kacang hijau.

Banyak penelitian yang menjelaskan secara terpisah tentang pengaruh cahaya dan media tanam terhadap pertumbuhan dan perkembangan perkecambahan kacang hijau. Namun penelitian yang bertujuan untuk menguji secara simultan pengaruh dari kedua faktor tersebut terhadap pertumbuhan dan perkembangan perkecambahan kacang hijau belum pernah dilakukan. Pengamatan terhadap respon pertumbuhan dan perkembangan perkecambahan dilakukan selama 7 hari. Oleh karena itu pada penelitian ini akan dilakukan percobaan dengan melibatkan dua faktor untuk melihat pengaruh interaksi antara cahaya dan media tanam dengan waktu terhadap respon yang akan diamati. Percobaan semacam ini disebut percobaan faktorial.

Percobaan faktorial dicirikan oleh perlakuan yang merupakan komposisi dari semua kemungkinan kombinasi dari taraf-taraf dua faktor atau lebih. Keuntungan dari percobaan faktorial yaitu mampu mendeteksi respon dari taraf masing-masing faktor (pengaruh utama) serta interaksi antara dua faktor (pengaruh sederhana) sedangkan RAL digunakan karena kondisi semua biji kacang hijau yang diletakkan pada unit percobaan dianggap memiliki kualitas yang seragam dan pemberian air dengan volume yang sama.

Dalam hal ini perancangannya lebih mengacu pada bagaimana kombinasi pelakuan yang akan diteliti disusun dan bagaimana pengalokasian kombinasi perlakuan tersebut ke dalam unit percobaan. Selain cara penyusunan dan penempatan kombinasi perlakuan, pengaruh waktu juga ikut berperan di dalam penelitian ini karena pengamatan terhadap panjang batang kecambah dilakukan dari hari ke hari selama 7 (tujuh) hari. Seiring bertambahnya waktu, diharapkan batang kecambah juga bertambah panjang dengan kondisi fisik yang sehat. Sesuai dengan tujuan perancangannya, maka rancangan yang cocok untuk digunakan adalah rancangan dengan pengamatan berulang menggunakan rancangan dasar yang melibatkan dua faktor dengan menggunakan rancangan lingkungan adalah rancangan acak lengkap (Faktorial dalam waktu RAL).

\section{METODE PENELITIAN}

\subsection{Kacang Hijau}

Kacang hijau merupakan salah satu tanaman semusim yang berumur pendek (kurang lebih 60 hari). Tanaman ini disebut juga mungbean, green gram atau golden gram. Tanaman kacang hijau berbatang tegak dengan ketinggian sangat bervariasi, antara $30-60 \mathrm{~cm}$, tergantung varietasnya. Cabangnya menyamping pada bagian utama, berbentuk bulat dan 
berbulu. Warna batang dan cabangnya ada yang hijau dan ada yang ungu. Daunnya trifoliate (terdiri dari tiga helaian) dan letaknya berseling. Tangkai daunnya cukup panjang, lebih panjang dari daunnya. Warna daunnya hijau muda sampai hijau tua. Bunga kacang hijau berwarna kuning, tersusun dalam tandan, keluar pada cabang serta batang, dan dapat menyerbuk sendiri. Polong kacang hijau berebntuk silindris dengan panjang antara 6-15 cm dan biasanya berbulu pendek. Sewaktu muda polong berwarna hijau dan dan setelah tua berwarna hitam atau coklat. Setiap polong berisi 10-15 biji.

Di dalam kacang hijau terdapat berbagai kandungan, antara lain : Protein (memperkuat daya tahan tubuh). Kalsium dan fosfor (memperkuat tulang). Vitamin B1 (membantu proses pertumbuhan dan menghasilkan energy). Vitamin B2 (membantu penyerapan protein dalam tubuh). Vitamin $\mathrm{E}$ (membantu meningkatkan kesuburan). Zat besi (membantu pembentukan sel darah merah). Magnesium (menjaga fungsi otot dan syaraf) dan rendah lemak. Terdapat antioksidan yang berguna bagi tubuh. http://id.wikipedia.org/wiki/kacang hijau

\subsection{Macam Perkecambahan}

Berdasarkan letak kotiledon pada saat perkecambahan, ada dua tipe perkecambahan, yaitu :

\subsubsection{Perkecambahan Epigeal}

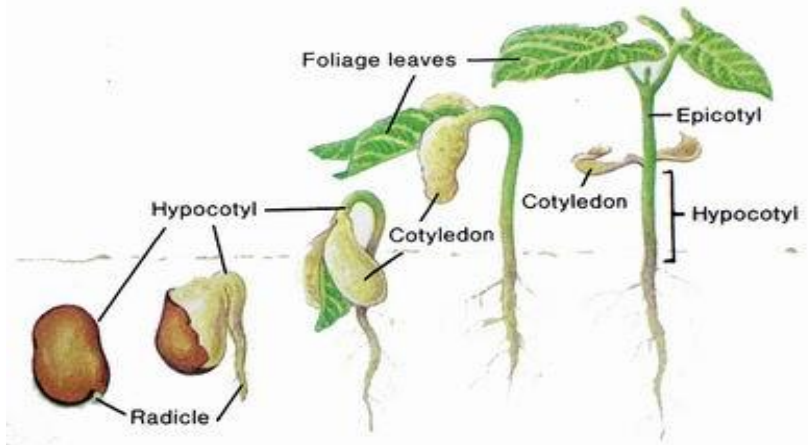

Gambar 1 : Perkecambahan Epigeal

Ciri Perkecambahan ini : Terangkatnya kotiledon dan plamula ke permukaan tanah. Pemanjangan terjadi pada bagian hipokotil (ruas batang dibawah kotiledon). Perkecambahan ini umumnya terjadi pada biji tanaman Dicotyledoneae (kecuali kacang kapri), contoh : kacang hijau, kacang kedelai, kapas. 
2.2.2. Perkecambahan Hipogeal

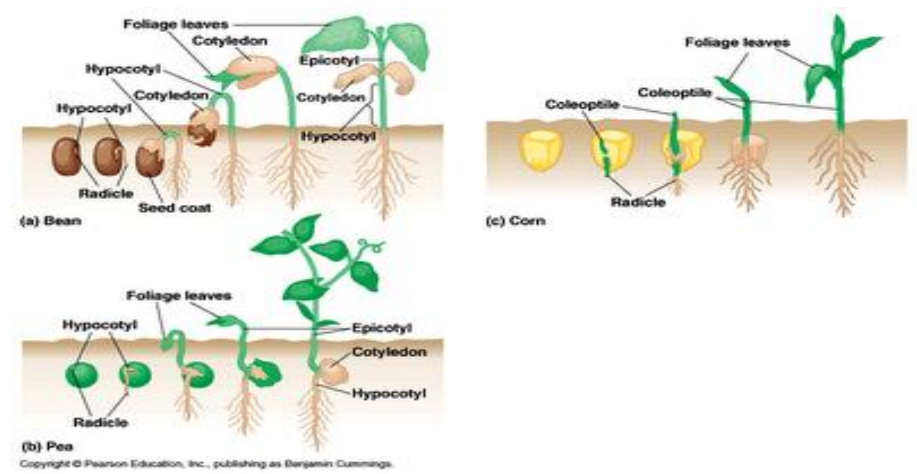

Gambar 2 : Perkecambahan Hipogeal

Ciri Perkecambahan ini : Tertinggalnya kotiledon didalam tanah, sedang plamula tetap menembus tanah. Pemanjangan terjadi pada epikotil (ruas batang diatas kotiledon). Umumnya terjadi pada biji monocotyleddoneae, contoh : Jagung, padi. dan Dicotyledoneae yaitu hanya kacang kapri.

Pada akhir perkecambahan terbentuk akar, batang dan daun. Selanjutnya, tumbuhan mengalami pertumbuhan, yaitu : pertumbuhan primer (pertumbuhan yang terjadi karena aktivitas meristem apical (terdapat pada ujung batang dan ujung akar), menyebabkan pemanjangan akar dan batang dan pertumbuhan Sekunder (pertumbuhan sekunder terjadi akibat aktivitas pembelahan mitosis pada jaringan meristem sekunder (lateral) sehingga mengakibatkan diameter batang dan akar bertambah besar. Meristem lateral terbagi atas : kambium vaskuler (terletak diantara xylem dan floem menyebabkan pembelahan sel kearah dalam membentuk xylem dan kearah luar membentuk floem dan kambium gabus (jaringan pelindung yang menggantikan fungsi jaringan epidermis yang rusak/mati). Pertumbuhan sekunder terjadi pada tumbuhan dikotil. http://id.wikipedia.org/wiki/perkecambahan

\subsection{Pengertian Pertumbuhan dan Perkembangan}

Pertumbuhan adalah proses bertambahnya ukuran (diantaranya volume, massa, dan tinggi) serta jumlah sel secara irreversible (tidak dapat kembali ke bentuk semula). Pertumbuhan bersifat kuantitatif (dapat diukur) menggunakan auksanometer. Pertumbuhan terjadi karena pertambahan jumlah sel dan pembesaran sel. Proses ini terjadi akibat pembelahan mitosis pada jaringan bersifat meristematik. Contoh, pertambahan tinggi batang dan jumlah daun. 
Perkembangan adalah proses terspesialisasi sel menuju ke bentuk dan fungsi tertentu yang mengarah ke tingkat kedewasaan yang bersifat kualitatif (tidak dapat dihitung) dan irreversible. Contoh, munculnya bunga sebagai alat perkembangbiakan.

\subsection{Faktor - Faktor yang Mempengaruhi Pertumbuhan dan Perkembangan Tumbuhan}

Menurut Mayer dan Mayber (1982) ada dua faktor yang mempengaruhi pertumbuhan dan perkembangan tumbuhan, yaitu :

Faktor Internal (Dalam)

Yang termasuk faktor internal adalah gen dan hormon.

Faktor Eksternal/Luar (Lingkungan)

a. Air

Air termasuk senyawa utama yang sangat dibutuhkan tumbuhan. Tanpa air, reaksi kimia dalam sel tidak berlangsung sehingga tumbuhan mati.

b. Cahaya

Kualitas, intensitas, dan lamanya radiasi yang mengenai tumbuhan mempunyai pengaruh yang besar terhadap berbagai proses fisiologi tumbuhan. Pada intensitas cahaya berlebih maka auksin dan klorofil akan rusak sehingga menghambat pertumbuhan. Sebaliknya, pada intensitas kurang cahaya tumbuhan mengalami etiolasi.

\section{c. Kelembapan}

Laju transpirasi dipengaruhi oleh kelembapan udara. Jika kelembapan udara rendah, transpirasi akan meningkat. Hal ini memacu akar untuk menyerap lebih banyak air dan mineral dari dalam tanah. Meningkatnya penyerapan nutrien oleh akar akan meningkatkan pertumbuhan tanaman.

d. Nutrien

Zat makanan bisa terdapat dalam air, udara, dan tanah (umumnya) dalam bentuk ion. Nutrien digunakan tumbuhan untuk sumber energy dan sumber materi untuk sintesis berbagaikomponen sel yang diperlukan selama pertumbuhan. Jika kebutuhan kurang maka akan terjadi defisiensi (tumbuh tidak sempurna hingga bisa mati). 
e. Suhu

Suhu berpengaruh dalm proses fotosintesis, respirasi, transpirasi, dan reproduksi. Pada suhu optimum (suhu tertentu saat tumbuh dan berkembang dengan baik berkisar $10-38^{\circ} \mathrm{C}$ ). Umumnya tumbuhan tidak tumbuh pada suhu $0^{\circ} \mathrm{C}$ dan diatas $40^{\circ} \mathrm{C}$.

\section{f. Oksigen}

Oksigen mempengaruhi pertumbuhan tumbuhan. Dalam respirasi aerob pada tumbuhan, terjadi penggunaan oksigen untuk menghasilkan energi. Energi ini digunakan, antara lain untuk pemecahan kulit biji dalam perkecambahan, dan aktivitas tumbuhan. Apabila tumbuhan kekurangan Oksigen dapat mengalami kematian.

g. $\quad \mathrm{pH}$ medium (Tingkat keasaman)

Derajat keasaman tanah $(\mathrm{pH}$ tanah) sangat berpengaruh terhadap ketersediaan unsur hara yang diperlukan oleh tumbuhan. Pada kondisi $\mathrm{pH}$ tanah netral unsur-unsur yang diperlukan, seperti $\mathrm{Ca}, \mathrm{Mg}, \mathrm{P}, \mathrm{K}$ cukup tersedia. Adapun pada $\mathrm{pH}$ asam, unsur yang tersedia adalah $\mathrm{Al}, \mathrm{Mo}, \mathrm{Zn}$, yang dapat meracuni tubuh tumbuhan.

\subsection{Rancangan Percobaan dengan Pengamatan Berulang (Repeated Measurement)}

Percobaan yang melibatkan pengamatan berulang sudah seharusnya memerlukan penanganan model analisis yang lain dari model rancangan dasar agar informasi yang diperoleh lebih luas. Disamping perlakuan yang dicobakan tentunya juga diharapkan mampu melihat pertumbuhan / perkembangan respon selama penelitian sehingga pengaruh waktu akan sangat bermanfaat untuk dikaji disamping perlakuan yang diberikan.

Percobaan seperti ini sering diberi nama sesuai dengan rancangan dasar yang dipakai ditambah "dalam waktu". Sebagai contoh jika rancangan dasar yang digunakan Faktorial maka rancangan dengan pengamatan berulang sering disebut Faktorial dalam waktu (Factorial in Time, tetapi jika rancangan dasarnya Petak Terpisah maka rancangan ini disebut Petak Terpisah dalam waktu (Split Plot in Time). (Mattjik AA \& Sumertajaya IM, 2000)

\subsection{Model Linier}

Sebagai contoh, untuk rancangan faktorial $2 \times 3$ dalam waktu dengan rancangan lingkungan RAL dapat dituliskan sebagai berikut :

$Y_{i j k l}=\mu+\alpha_{i}+\beta_{j}+\alpha \beta_{i j}+\delta_{i j k}+\omega_{l}+\gamma_{k l}+\alpha \omega_{i l}+\beta \omega_{j l}+\alpha \beta \omega_{i j l}+\varepsilon_{i j k l}$. 
dimana : Yijkl nilai respon pada faktor A taraf ke-i, faktor B taraf ke-j, ulangan ke-k dan waktu pengamatan ke-l, $\mu$ rataan umum, $\alpha_{i}$ pengaruh faktor $A$ taraf ke-i, $\beta_{j}$ pengaruh faktor $B$ taraf ke-j, $\alpha \beta_{i j}$ pengaruh interaksi faktor $A$ dengan faktor $B, \delta_{i j k}$ komponen acak perlakuan, $\omega_{I}$ pengaruh waktu pengamatan ke-l, $\gamma_{k l}$ komponen acak waktu pengamatan, $\alpha \omega_{i l}$ pengaruh interaksi waktu dengan faktor $A, \beta \omega_{j l}$ pengaruh interaksi waktu dengan faktor $B, \alpha \beta \omega_{i j l}$ pengaruh interaksi faktor $A$, faktor $B$ dengan waktu, dan $\varepsilon_{\mathrm{jjkl}}$ komponen acak dari interaksi waktu dengan perlakuan.

\subsection{Sumber-sumber Keragaman}

Penguraian keragaman total akan dilakukan untuk faktorial $A x B$ dalam waktu dengan rancangan lingkungan RAL. Sebagai kasus faktor $A$ terdiri dari a taraf, faktor $B$ terdiri dari $b$ taraf dan setiap perlakuan diulang sebanyak $r$ kali. Pengamatan dilakukan sebanyak $c$ kali, maka sumber-sumber keragaman yang muncul dapat dilihat pada tabel sidik ragam berikut :

Tabel 1 : Sidik ragam untuk rancangan faktorial dalam waktu RAL

\begin{tabular}{|c|c|c|c|c|c|}
\hline $\begin{array}{c}\text { Sumber } \\
\text { Keragaman }\end{array}$ & $\mathrm{db}$ & $\begin{array}{l}\text { Jumlah } \\
\text { Kuadrat }\end{array}$ & $\begin{array}{l}\text { Kuadrat } \\
\text { Tengah }\end{array}$ & F-hitung & F-tabel \\
\hline Faktor A & $a-1$ & JKA & KTA & KTA/KTG(a) & $F_{(a, d b-A, ~ d b-G(a))}$ \\
\hline Faktor B & $b-1$ & JKB & KTB & KTB/KTG(a) & $F_{(a, d b-B, d b-G(a))}$ \\
\hline Interaksi $A^{*} B$ & $(a-1)(b-1)$ & JKAB & KTAB & KTAB/KTG(a) & $F_{(a, d b-A B, d b-G(a))}$ \\
\hline Galat (a) & $a b(r-1)$ & $J K G(a)$ & KTG(a) & & \\
\hline Waktu W & $c-1$ & JKC & KTC & KTC/KTG(b) & $\mathrm{F}_{(\mathrm{a}, \mathrm{db}-\mathrm{A}, \mathrm{db}-\mathrm{G}(\mathrm{b}))}$ \\
\hline Galat (b) & $c(r-1)$ & $J K G(b)$ & $\mathrm{KTG}(\mathrm{b})$ & & \\
\hline Interaksi $A^{*} W$ & $(a-1)(c-1)$ & JKAC & KTAC & KTAC/KTG(c) & $\mathrm{F}_{(\mathrm{a}, \mathrm{db}-\mathrm{AW}, \mathrm{db}-\mathrm{G}(\mathrm{c}))}$ \\
\hline Interaksi B*W & $(b-1)(c-1)$ & JKBC & KTBC & KTBC/KTG(c) & $\mathrm{F}_{(\mathrm{a}, \mathrm{db}-\mathrm{BW}, \mathrm{db}-\mathrm{G}(\mathrm{c}))}$ \\
\hline Interaksi $A^{*} B^{*} W$ & $(a-1)(b-1)(c-1)$ & JKABC & KTABC & KTABC/KTG(c) & $F_{(\alpha, d b-A B W, ~ d b-G(c))}$ \\
\hline Galat (c) & $(a b c-a b-c)(r-1)$ & JKG(c) & $\mathrm{KTG}(\mathrm{c})$ & & \\
\hline Total & abcr-1 & JKT & & & \\
\hline
\end{tabular}

\section{HASIL DAN PEMBAHASAN}

Tabel 2 : Hasil Pertumbuhan Kecambah Kacang Hijau

\begin{tabular}{|c|c|c|c|c|c|c|c|c|c|}
\hline \multirow{2}{*}{$\begin{array}{c}\text { Intensitas } \\
\text { Cahaya }\end{array}$} & \multirow{2}{*}{$\begin{array}{c}\text { Media } \\
\text { Tanam }\end{array}$} & \multirow{2}{*}{ Ulangan } & \multicolumn{6}{|c|}{ Panjang Batang Kecambah (cm) Pada Hari Ke- } \\
\cline { 4 - 11 } & & & C1 & C2 & C3 & C4 & C5 & C6 & C7 \\
\hline \multirow{2}{*}{$\begin{array}{c}\text { Gelap } \\
\text { (IC1) }\end{array}$} & $\begin{array}{c}\text { Tanah } \\
\text { (MT1) }\end{array}$ & 1 & 0,52 & 0,62 & 3,90 & 9,30 & 11,50 & 24,30 & 30,40 \\
\cline { 3 - 12 } & & 2 & 0,78 & 0,86 & 3,98 & 11,70 & 15,45 & 28,50 & 34,40 \\
\cline { 3 - 11 } & & 3 & 0,76 & 0,94 & 3,30 & 6,50 & 11,33 & 25,24 & 32,00 \\
\hline
\end{tabular}




\begin{tabular}{|c|c|c|c|c|c|c|c|c|c|}
\hline & \multirow{3}{*}{$\begin{array}{l}\text { Kapas } \\
\text { (MT2) }\end{array}$} & 1 & 0,48 & 0,66 & 2,44 & 3,66 & 7,75 & 11,77 & 16,38 \\
\hline & & 2 & 0,76 & 0,94 & 2,04 & 6,14 & 10,80 & 15,00 & 19,94 \\
\hline & & 3 & 0,94 & 1,06 & 2,40 & 3,90 & 9,21 & 14,39 & 18,88 \\
\hline \multirow{6}{*}{$\begin{array}{l}\text { Redup } \\
\text { (IC2) }\end{array}$} & \multirow{3}{*}{$\begin{array}{l}\text { Tanah } \\
\text { (MT1) }\end{array}$} & 1 & 0,98 & 2,78 & 10,60 & 18,50 & 23,90 & 31,00 & 38,09 \\
\hline & & 2 & 1,04 & 3,08 & 10,40 & 20,60 & 24,75 & 30,90 & 37,66 \\
\hline & & 3 & 0,58 & 2,44 & 9,64 & 16,80 & 21,00 & 27,54 & 34,00 \\
\hline & \multirow{3}{*}{$\begin{array}{l}\text { Kapas } \\
\text { (MT2) }\end{array}$} & 1 & 0,24 & 0,56 & 1,08 & 2,96 & 11,25 & 18,67 & 26,25 \\
\hline & & 2 & 1,08 & 1,60 & 8,50 & 18,30 & 25,40 & 32,00 & 36,67 \\
\hline & & 3 & 0,50 & 0,96 & 2,66 & 5,08 & 12,85 & 18,89 & 26,55 \\
\hline \multirow{6}{*}{$\begin{array}{c}\text { Terang } \\
\text { (IC3) }\end{array}$} & \multirow{3}{*}{$\begin{array}{l}\text { Tanah } \\
\text { (MT1) }\end{array}$} & 1 & 0,14 & 0,20 & 4,20 & 7,24 & 8,03 & 10,23 & 12,73 \\
\hline & & 2 & 0,20 & 0,26 & 2,02 & 3,80 & 6,12 & 8,64 & 12,77 \\
\hline & & 3 & 0,18 & 0,24 & 1,70 & 2,64 & 5,56 & 8,64 & 11,00 \\
\hline & \multirow{3}{*}{$\begin{array}{l}\text { Kapas } \\
\text { (MT2) }\end{array}$} & 1 & 0,05 & 0,15 & 0,32 & 0,50 & 0,75 & 0,90 & 1,03 \\
\hline & & 2 & 0,00 & 0,00 & 0,01 & 0,02 & 0,03 & 0,03 & 0,05 \\
\hline & & 3 & 0,14 & 0,22 & 0,28 & 0,28 & 0,29 & 0,29 & 0,32 \\
\hline
\end{tabular}

\subsection{Uraian Singkat llustrasi Percobaan dalam Penelitian}

Pada penelitian ini akan dilakukan percobaan tentang pertumbuhan dan perkembangan kecambah kacang hijau yang diberikan 2 buah perlakuan yaitu intensitas cahaya (IC) dan media tanam (MT), dimana masing-masing perlakuan terdiri dari level yang berbeda. Untuk faktor intensitas cahaya terbagi atas 3 level yaitu IC1 (Gelap), IC2 (Redup) dan IC3 (Terang) sedangkan faktor media tanam terdiri dari 2 level yaitu MT1 (Tanah) dan MT2 (Kapas). Dengan demikian banyaknya perlakuan yang dicobakan adalah $3 \times 2=6$ kombinasi perlakuan. Setiap kombinasi perlakuan diulang sebanyak 3 kali sehingga banyaknya petak percobaan yang digunakan adalah $6 \times 3=18$ unit percobaan. Pengamatan dilakukan selama 7 hari. Setiap kombinasi perlakuan yang diletakkan pada unit percobaan diberikan volume air yang seragam.

\subsection{Deskripsi Data}

Berdasarkan pengamatan yang dilakukan menunjukkan adanya perbedaan pertumbuhan dan perkembangan biji kacang hijau dari hari ke hari. Kian hari biji yang berubah menjadi kecambah tumbuh dan berkembang semakin panjang. Hal ini mengindikasikan bahwa waktu mempengaruhi pertumbuhan dan perkembangan perkecambahan. Pertumbuhan dan perkembangan biji kacang hijau berbeda-beda tergantung pada seberapa besar tumbuhan tersebut memperoleh cahaya dan jenis media tanamnya. 
Dari gambar 3 terlihat untuk kombinasi perlakuan C2N1 dan C2N2, batang kecambah lebih panjang dibandingkan dengan kombinasi perlakuan yang lain. Hal ini dipengaruhi adanya hormon auksin. Pada keadaan yang tidak terkena matahari secara langsung, hormon auksin ini tidak terurai secara sempurna sehingga akan terus memacu pemanjangan batang. Akibatnya, batang tanaman akan lebih panjang jika ditanam di tempat yang redup dan gelap. Meskipun pertumbuhannya baik, tetapi perkembangannya kurang baik dengan kondisi fisik batang kecambah yang kurang sehat, akar yang banyak dan lebat, warna batang dan daun pucat serta kekurangan klorofil sehingga daun berwarna kuning. Demikian pula halnya dengan kombinasi perlakuan $\mathrm{C} 1 \mathrm{~N} 1$. Sedangkan panjang batang kecambah pada kombinasi perlakuan $\mathrm{C} 3 \mathrm{~N} 1$ sangat lambat tetapi kondisi batangnya tegak dan kokoh, warna batangnya ungu muda dan daunnya lebar berwarna hijau tua.

Interaksi antara kombinasi perlakuan mengakibatkan perbedaan yang signifikan dalam hal pertumbuhan dan perkembangan perkecambahan kacang hijau, namun perbedaan yang ditimbulkan antar perlakuan tidak begitu nyata. Pada gambar tidak terlihat adanya perbedaan panjang batang tanaman berdasarkan media tanamnya. Biji kacang hijau yang ditanam di tanah dan di kapas tidak menunjukkan adanya perbedaan. Kecuali panjang batang tanaman pada kombinasi perlakuan C3N1 dengan C3N2.

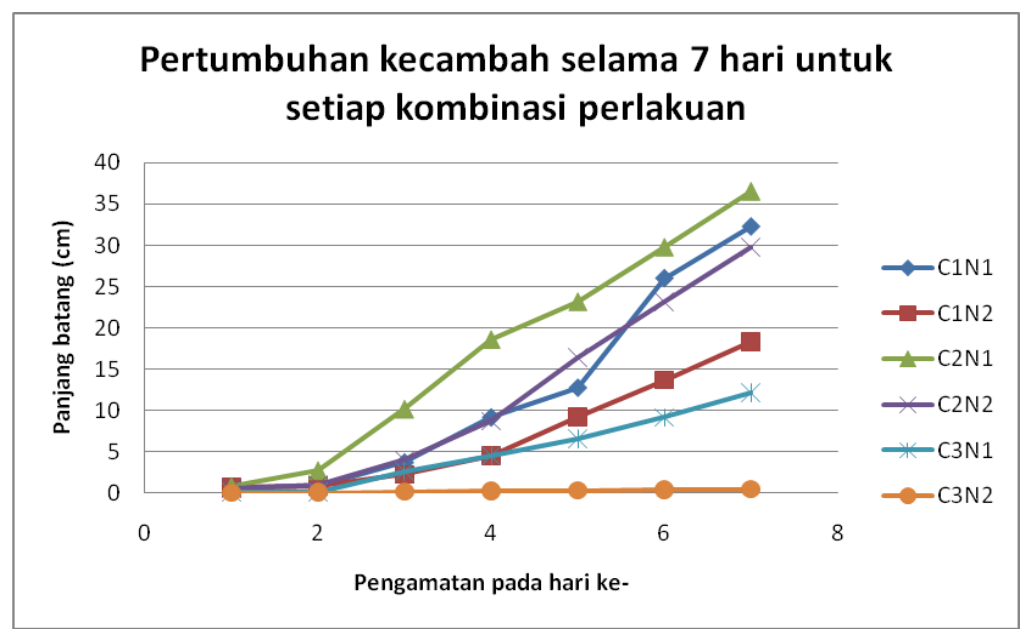

Gambar 3 : Grafik panjang batang dalam waktu pengamatan 


\subsection{Struktur Tabel Sidik Ragam}

Hasil Analisis Faktorial dalam Waktu RAL

The GLM Procedure

Class Level Information

Class

Levels Values

IC

3123

MT

212

$\mathrm{R}$

3123

C

7

1234567

Number of Observations Read $\quad 126$

Number of Observations Used 126

Dependent Variable: RESPON

Sum of

$\begin{array}{lclccc}\text { Source } & \text { DF } & \text { Squares } & \text { Mean Square } & \text { F Value } & \text { Pr }>\text { F } \\ \text { Model } & 65 & 14052.91318 & 216.19866 & 101.12 & <.0001 \\ \text { Error } & 60 & 128.28109 & 2.13802 & & \\ \text { Corrected Total } & 125 & 14181.19427 & & & \end{array}$

$\begin{array}{llll}\text { R-Square } & \text { Coeff Var } & \text { Root MSE } & \text { RESPON Mean } \\ 0.990954 & 16.21303 & 1.462196 & 9.018651\end{array}$

$\begin{array}{cccccc}\text { Source } & \text { DF } & \text { Type I SS } & \text { Mean Square } & \text { F Value } & \text { Pr }>\text { F } \\ \text { IC } & 2 & 3075.720487 & 1537.860244 & 719.29 & <.0001 \\ \text { MT } & 1 & 822.122401 & 822.122401 & 384.53 & <.0001 \\ \text { IC*MT } & 2 & 2.132240 & 1.066120 & 0.50 & 0.6098 \\ \text { R(IC*MT }) & 12 & 407.269686 & 33.939140 & 15.87 & <.0001 \\ \text { C } & 6 & 7101.020021 & 1183.503337 & 553.55 & <.0001 \\ \text { R(C) } & 12 & 62.276489 & 5.189707 & 2.43 & 0.0121 \\ \text { IC*C } & 12 & 2014.485079 & 167.873757 & 78.52 & <.0001 \\ \mathrm{MT}^{*} \mathrm{C} & 6 & 445.999249 & 74.333208 & 34.77 & <.0001 \\ \mathrm{IC}^{*} \mathrm{MT}^{*} \mathrm{C} & 12 & 121.887527 & 10.157294 & 4.75 & <.0001\end{array}$


Dari tabel sidik ragam yang diperoleh dari output SAS di atas memberikan kesimpulan bahwa faktor intensitas cahaya (IC), media tanam (MT), waktu (C), interaksi IC*C, interaksi $M T^{*} \mathrm{C}$ dan interaksi $I C^{*} \mathrm{MT}{ }^{*} \mathrm{C}$ berpengaruh nyata terhadap respon yang diamati yang ditunjukkan dengan perolehan nilai $p$ sebesar 0,0001 yang kurang dari taraf nyata $\alpha=5 \%$ sedangkan untuk interaksi antara IC*MT tidak berpengaruh nyata terhadap respon yang diamati (nilai $p=0,6098>0,05$ ). Artinya bahwa pengaruh waktu sangat menentukan pertumbuhan dan perkembangan perkecambahan kacang hijau. Dari waktu ke waktu, kecambah tumbuh dan berkembang menjadi lebih panjang dengan kondisi fisik yang berbeda-beda. Hal ini menunjukkan meskipun kacang hijau ditanam pada media tanam dan memperoleh intensitas cahaya yang bervariasi, namun pertumbuhan dan perkembangannya seiring dengan bertambahnya waktu.

Berdasarkan hasil dari perbandingan berganda Duncan diperoleh fakta bahwa IC2 berbeda nyata dengan IC1 dan IC3. Respon pertumbuhan batang tanaman untuk faktor IC2 lebih panjang dibandingkan IC1 dan IC3. Demikian pula halnya dengan MT1 berbeda nyata dengan MT2. MT1 menghasilkan pertumbuhan respon lebih panjang jika dibandingkan dengan MT2. Sedangkan pengaruh waktu C1, C2, C3, C4, C5, C6 dan C7 sangat berbeda nyata terhadap respon yang diamati.

\section{KESIMPULAN}

1. Hasil dari tabel sidik ragam menunjukkan bahwa faktor intensitas cahaya (IC), media tanam (MT), waktu (C), interaksi $I C^{*} \mathrm{C}$, interaksi $\mathrm{MT}^{*} \mathrm{C}$ dan interaksi $I \mathrm{C}^{*} \mathrm{MT}^{*} \mathrm{C}$ berpengaruh nyata terhadap respon yang diamati yang ditunjukkan dengan perolehan nilai $\mathrm{p}$ yang kurang dari taraf nyata $5 \%(0,0001)$ sedangkan untuk interaksi antara IC*MT tidak berpengaruh nyata terhadap respon yang diamati (nilai $p=0,6098>0,05$ ).

2. Berdasarkan hasil dari perbandingan berganda Duncan diperoleh fakta bahwa IC2 berbeda nyata dengan IC1 dan IC3. Respon pertumbuhan batang tanaman untuk faktor IC2 lebih panjang dibandingkan IC1 dan IC3. Demikian pula halnya dengan MT1 berbeda nyata dengan MT2. MT1 menghasilkan pertumbuhan respon lebih panjang jika dibandingkan dengan MT2. Sedangkan pengaruh waktu C1, C2, C3, C4, C5, C6 dan C7 sangat berbeda nyata terhadap respon yang diamati. Hal ini terbukti dengan semakin panjangnya batang tanaman seiring dengan bertambahnya waktu. 


\section{DAFTAR PUSTAKA}

[1]. Aunuddin. 2005. Rancangan dan Analisis Data. IPB Press. Bogor.

[2]. Gomez, KA \& Gomez AA. 1995. Prosedur Statistik untuk Penelitian Pertanian. UI Press. Jakarta

[3]. Mattjik AA \& Sumertajaya IM 2000. Perancangan Percobaan dengan Aplikasi SAS dan Minitab jilid 1. IPB Press. Bogor.

[4]. Mayer AM \& Mayber AP 1982. The Germination of Seeds. Pergamon Press. New York. 192.

[5]. http://id.wikipedia.org/wiki/perkecambahan.

[6]. http://id.wikipedia.org/wiki/kacang hijau. 


\section{LAMPIRAN}
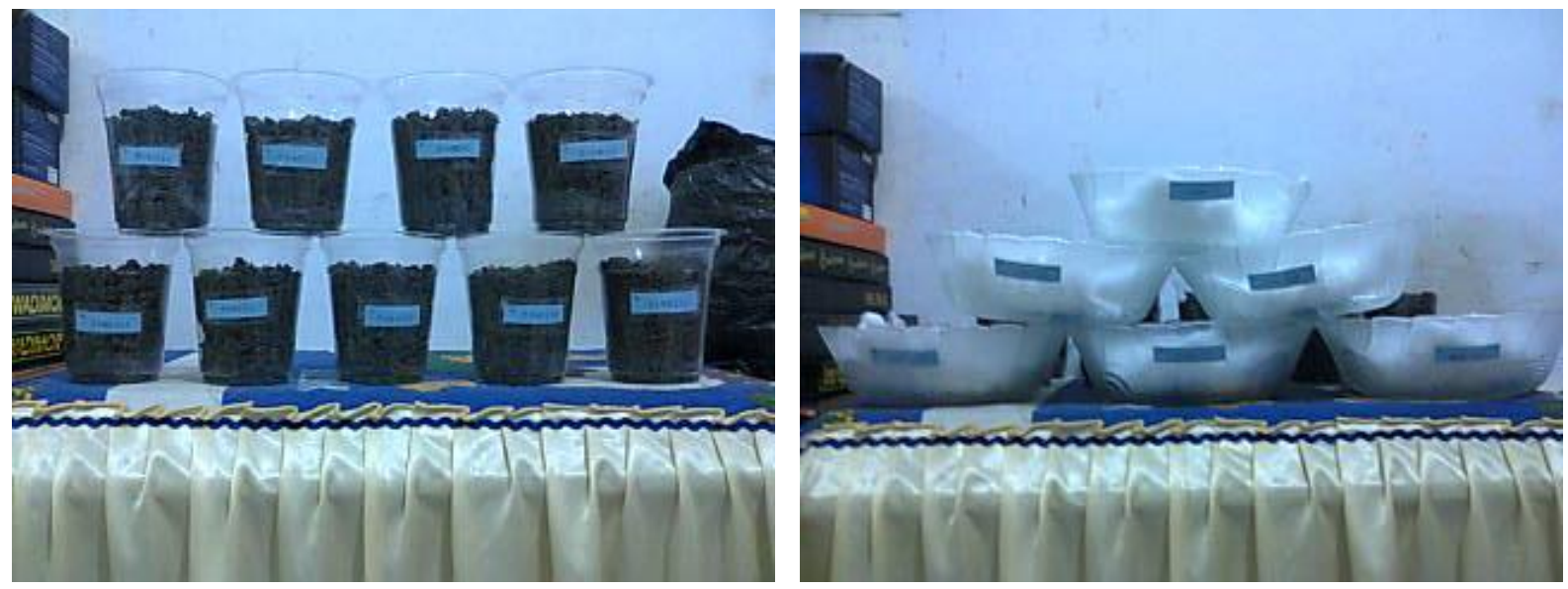

Gambar Media Tanah dan Kapas sebagai Unit Percobaan
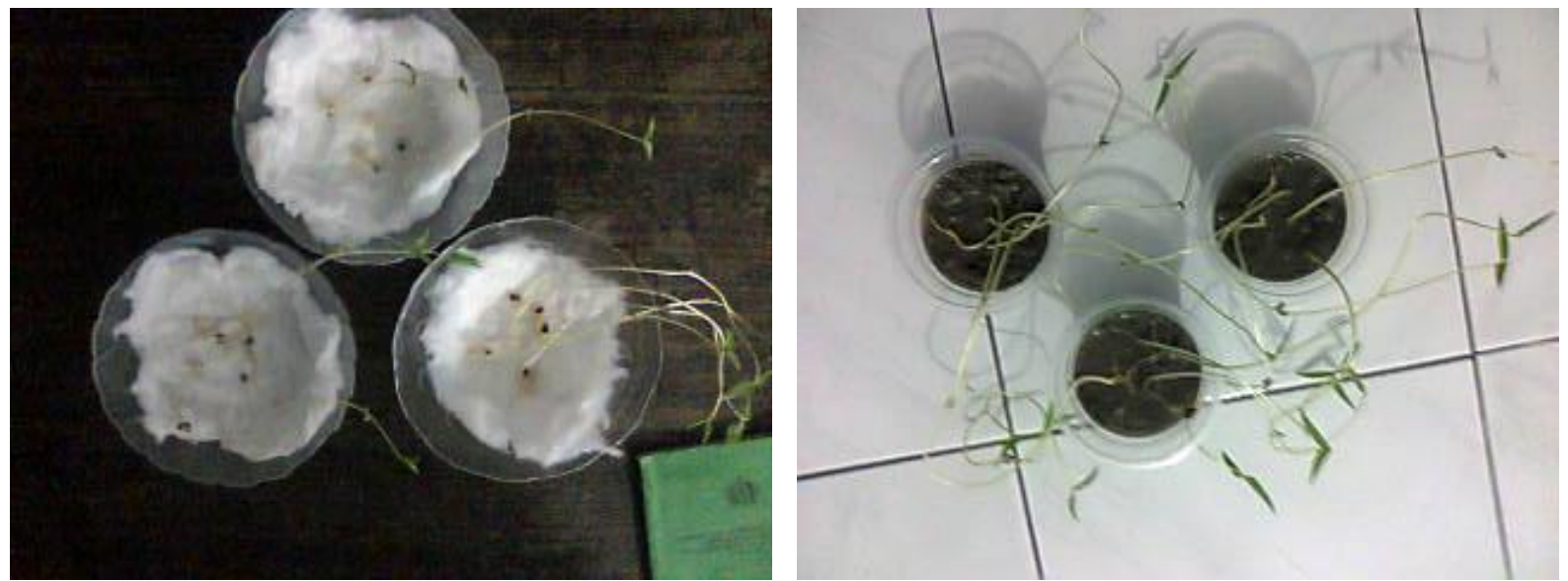

Gambar Pertumbuhan dan Perkembangan Kecambah pada Media Tanah dan Kapas sebagai Unit Percobaan 